\title{
The Fascist Who Fought for World Peace: \\ Conversions and Core Concepts in the Ideology of the Swedish Nazi Leader Sven Olov Lindholm
}

\author{
Johan Stenfeldt \\ Dept of History, Lund University, Sweden \\ johan.stenfeldt@hist.lu.se
}

\begin{abstract}
This article deals with the political conversion and ideological thought of the Swedish National Socialist Sven Olov Lindholm (1903-1998). Lindholm began his career as a fascist in the twenties, and became a member of Sweden's main National Socialist party led by Birger Furugård, in the early thirties. Ideological divisions and a failed attempt to oust Furugård saw Lindholm found his own party in January 1933, the NSAP (later renamed the sss). Previous research has often described this party as a left-wing Nazi alternative, but its ideological basis has never been thoroughly dissected. The present article uses a variety of archival collections, speeches, pamphlets, and newspaper articles to suggest a cluster of six interdependent core concepts in Sven Olov Lindholm's ideological thought: anti-Semitism, anti-capitalism, anti-imperialism, anti-materialism, the idealization of the worker, and the definition of Nazi Germany as a worker's state. Lindholm underwent a second political awakening in the sixties, redefining himself as a communist, and thus the article also examines the ideological remains thereafter. It is found that anti-materialism, linked to a broad antipathy to modernity, was central throughout his career.
\end{abstract}

\section{Keywords}

Sweden - fascism - National Socialism - socialism - Sven Olov Lindholm - ideological conversion 
The aim of this article is to dissect key elements in the ideological thought of the Swedish Nazi leader Sven Olov Lindholm (1903-1998). ${ }^{1}$ On a conceptual level, Lindholm started his political career as a 'fascist', one of the leading figures in Sveriges Fascistiska Kamporganisation [sFKO; Sweden's Fascist Combat Organization]. After attending the Nuremberg rally in 1929, where he met Adolf Hitler, along with Julius Streicher, GregorStrasser, and Gottfried Feder, he and the greater part of the SFKo redefined themselves as 'National Socialists' and were incorporated into the existing Swedish National Socialist movement led by Birger Furugård. In the new party that was formed, Svenska Nationalsocialistiska Partiet [SNSP; Sweden's National Socialist Party], Lindholm became editor-in-chief of the party newspaper. At an early stage, however, ideological divisions were evident in the SNSP. While Furugård's relation to the German party was utterly servile, Lindholm advocated a more independent course. Lindholm also fought against what he thought of as the party's bourgeois tendencies, and stated that the socialism of National Socialism was to be regarded as a firm ideological base and not as a mere tactic. Because of personal and ideological tensions, Lindholm arranged a coup to dislodge Furugård from the leadership. When this failed in January 1933, Lindholm left to found a new party, Nationalsocialistiska Arbetarpartiet [NSAP, National Socialist Workers' Party]. The NSAP became the leading National Socialist party of Sweden in the thirties, counted by votes. It was renamed Svensk Socialistisk Samling [sss, Swedish Socialist Unity] in 1938, and is sometimes denoted Sweden's 'left-wing' Nazi alternative, in contrast to the more stridently upper-class nationalist groups. Lindholm remained leader of the party until the end.

After a peak in the general election of 1936, the NSAP-sss gradually dwindled into insignificance, but it was not dissolved until 1950. Lindholm, who before his political career had served as a non-commissioned officer in the artillery, changed direction to become a stockroom worker and manager. He remarried after his first wife, Kersti, died of leukemia in 1941, and with his second wife, Vera, he became a father and tried to cope with the normalcy of everyday life. In the sixties, however, he experienced a second political awakening. His newborn radicalism is evident in the later versions of his political pamphlet Döm ingen ohörd [Condemn none unheard] in the late sixties, which was based on themes frequently expressed by the New Left in the sixties and seventies: the global redistribution of wealth, environmentalism, and strong criticism of American 'imperialist aggression' in Vietnam. He was against nuclear power, and became a member of the Swedish peace movement. In this sense he made

1 This article presents research kindly funded by Crafoordska stiftelsen, Erik Philip-Sörensens stiftelse, Helge Ax:son Johnsons stiftelse, Karl Staaffs fond för frisinnade ändamål, and Marcus och Amalia Wallenbergs minnesfond. 
a genuine conversion, for where he had opposed Swedish disarmament in the twenties he was now a peace activist in the eighties. ${ }^{2}$ Several times, he declared that he now defined himself as a communist, and that he voted for the Swedish Communist Party. This process also led to a profound political falling out with Vera, a life-long Nazi of German descent, which ended in their divorce. She went on to marry Göran Assar Oredsson, and together they became leading figures in nationalist circles in postwar Sweden. ${ }^{3}$

A biographical case study of Sven Olov Lindholm and his remarkable conversion is overdue for several reasons. The first is an obvious one: no biography exists. Of course, Lindholm's party has been studied by other scholars, but most often as part of the wider Swedish Nazi movement, with a marked focus on its generic traits. In another example of this tendency, it should be noted that full biographies of other prominent figures in this ideological environment such as Birger Furugård or Per Engdahl also remain to be written. ${ }^{4}$ There have been several studies of and books about 'Swedish Nazism', but few have dwelt on its subsets. ${ }^{5}$ The second reason, closely interconnected to the first, is that the

2 His conversion was a key element in Ingmar Svensson, 'Nazistledare lärde om nu är han fredskämpe,' Ny Dag 7 (1984), in what was probably the last interview with Lindholm, published in a left-wing Swedish newspaper. His trajectory from fascism to peace activism gave the title of the article.

3 Parts of this biographical sketch are given in Heléne Lööw, Nazismen i Sverige 1924-1979 (Stockholm: Ordfront, 2004). For the period after 1950, see Sven Olov Lindholm's personal archives, held by the Swedish National Archives (here after: RA).

4 For Engdahl, however, there are two articles: Conny Mithander, "Let Us Forget the Evil Memories": Nazism and the Second World War from the Perspective of a Swedish Fascist,' in Collective Traumas: Memories of War and Conflict in Twentieth-Century Europe, ed. Conny Mithander, John Sundholm and Maria Holmgren Troy (Brussels: Peter Lang, 2007), 179-213; and Lena Berggren, 'Intellectual Fascism: Per Engdahl and the Formation of "New-Swedish Socialism", Fascism: Journal of Comparative Fascist Studies 3 (2014): 69-92, https://doi.org/ 10.1163/22116257-00302001.

5 For this holistic approach to trends, see Holger Carlsson, Nazismen i Sverige (Stockholm: Trots allt, 1942); Armas Sastamoinen, Hitlers svenska förtrupper (Stockholm: Federativ, 1947); Åke Thulstrup, Med lock och pock (Stockholm: Bonniers, 1962); Eric Wärenstam, Fascismen och nazismen i Sverige 1920-1940 (Stockholm: Almqvist \& Wiksell, 1970); Ulf Lindström, Fascism in Scandinavia 1920-1940 (Stockholm: Almqvist \& Wiksell, 1985); Heléne Lööw, Hakkorset och Wasakärven (PhD diss., University of Gothenburg, 1990); Karl N. Alvar Nilsson, Svensk överklass och högerextremism under 19oo-talet (Stockholm: Federativ, 200o); and Lööw, Nazismen i Sverige 1924-1979. In focusing on the broader picture, some concentrate on links to Nazi Germany (Thulstrup, Med lock och pock), while others are written mainly as political statements (Carlsson, Nazismen i Sverige; Sastamoinen, Hitlers svenska förtrupper; Nilsson, Svensk överklass). 
broad focus on the Nazi phenomenon in its entirety-its organizations, parties, and membership - has resulted in what may be regarded as a mapping rather than detailed analyses. Much of this work has been presented in pioneering studies, but despite the scholarly advances in the field I would argue that a number of supplementary studies, chiseling out different biographical, conceptual, and ideological aspects to Swedish Nazism, are needed to bridge the gaps. ${ }^{6}$

That said, in recent years there have been a couple of contributions to the field that focus on Lindholm and his party. In his book En idé större än döden [An idea greater than death] from 2014, Victor Lundberg focuses on the proworking-class rhetoric of Lindholm's party, and defines it as a 'fascist workingclass movement'. Lundberg dismisses the idea that it was empty rhetoric - on the contrary, 'labor' and 'the worker' were held in high esteem-but makes the point that they were defined in a way that had nothing in common with Marxism. The ultimate goal of Marxism was to relieve the worker from the burden of productive labor; according to Lundberg, the function of labor in Lindholm's propaganda was instead to prove the stamina of the worker and make him ready for struggle - a fundamentally positive view that guaranteed there would be a genuine state of opposition between Lindholm's and Marx's thinking. Lundberg also claims that the German philosopher and officer Ernst Jünger was Lindholm's main ideological inspiration, thereby suggesting that Lindholm's movement should be seen as integrated into European fascism, with marked German influences. Therefore, he regards Lindholm's references to Swedish culture and the Swedish context of minor importance. ${ }^{7}$ When it comes to labor, I cannot agree with all of Lundberg's claims, for Lindholm's views on labor were not always positive, as we shall see. And it is also striking that there is no empirical evidence that supports Lundberg's idea that Jünger influenced Lindholm's thinking.

6 Others have noted similar lacunae. See for example Lena Berggren, 'Den svenska mellankrigsfascismen: Ett ointressant marginalfenomen eller ett viktigt forskningsobjekt?' Historisk tidskrift 122 (2002): 427-444; Johan Östling, 'Nya nyanser av brunt: Utblick över ett forskningsfält,' in De intellektuellas förräderi? Intellektuellt utbyte mellan Sverige och Tredje riket, ed. Maria Björkman, Patrik Lundell and Sven Widmalm (Lund: Arkiv, 2016), 337-350.

7 Victor Lundberg, En idé större än döden (Möklinta: Gidlunds, 2014). See also Victor Lundberg, 'Within the Fascist World of Work: Sven Olov Lindholm, Ernst Jünger and the Pursuit of Proletarian Fascism in Sweden, 1933-1945,' in New Political Ideas in the Aftermath of the Great War, ed. Alessandro Salvador and Anders G. Kjøstvedt (New York: Palgrave Macmillan, 2017), 199-217. 
This lack of evidence is also noted by Nathaniël Kunkeler in an article about Lindholm's literary inspiration. ${ }^{8}$ Kunkeler traces some of Lindholm's ideology to a Swedish romantic literary tradition, a tradition he refers to as 'Gothicism', and authors such as Verner von Heidenstam, Esaias Tegnér, and, perhaps most prominently, Viktor Rydberg. Key here is Lindholm's use of Rydberg's 'Den nya Grottesången' [The New Song of Grotte], a retelling of the Old Norse Poem Gróttasöngr, a text that according to Kunkeler 'appealed to his socialism. ${ }^{9}$ It is known to have appealed to other socialists as well, and for the labor movement of the early twentieth century the concept of the 'Grottekvarn', a mythological millstone worked for eternity by two giantesses in Rydberg's poem, was used as a metaphor for the relentless manual labor demanded by industrial society.10

The use of Rydberg indicated by Kunkeler calls into question the true nature of the Lindholm party's views on manual labor, but the influence of Swedish literature focused by Kunkeler also nuances Lundberg's argument about the importance of international influences. As another example of this tendency, Kunkeler, in another article not focusing on Lindholm, questions whether 'the nation' was actually at the heart of the Swedish brand of fascism during the thirties. ${ }^{11}$ Kunkeler's article is an important contribution to the field. He naturally concentrates on the impact of literature that Lindholm evidently read (and I share his hesitation about the influence of Jünger that is posited by Lundberg), but I would counter that Lindholm often refers to literary works, but not particularly in the party press. We need to focus on more than just literary inspiration if we are to successfully anatomize his ideology.

Since ideological conversion and relations between different ideologies are the topics here, what then of the literature on the relation between fascist, national socialist, and communist or New Left ideology? It is a huge field, of course-even excluding the literature on 'totalitarianism', since the fifties a common shorthand for fascism/national socialism and communism ${ }^{12}$-so only the most relevant contributions have been noted.

8 Nathaniël Kunkeler, 'Sven Olov Lindholm and the Literary Inspirations of Swedish Fascism,' Scandinavian Journal of History 44 (2019): 77-102.

$9 \quad$ Kunkeler, 'Sven Olov Lindholm and the Literary Inspirations of Swedish Fascism,' 86.

10 See Jimmy Vulovic, Reform eller revolt: Litterär propaganda $i$ socialdemokratisk, kommunistisk och nationalsocialistisk press (Lund: Ellerströms, 2013); Emma Hilborn, Världar i Brand: Fiktion, politik och romantik i det tidiga 19oo-talets ungsocialistiska press (Höör: Agering, 2014).

11 Nathaniël Kunkeler, "The Evolution of Swedish Fascism: Self-Identification and Ideology in Interwar Sweden,' Patterns of Prejudice 50 (2016): 378-397.

12 Classic examples are Hannah Arendt, The Origins of Totalitarianism (New York: Harcourt, Brace, 1951); and Carl J. Friedrich and Zbigniew Brzezinski, Totalitarian Dictatorship and 
It is often assumed that the ideologies of fascism and National Socialism are synonymous (which applies to Swedish fascism/National Socialism as well), or that National Socialism is a variety of fascism. ${ }^{13}$ The distinctions that have attracted attention tend to be national. Thus there is a body of literature on the distinctions between German and Italian fascism, which concentrates on the importance of anti-Semitism - a 'cornerstone' of German National Socialism, but not of Italian Fascism, Renzo de Felice and others observed..$^{14}$ Since Lindholm first defined himself as fascist and a member of a fascist combat organization, but later redefined himself as National Socialist - and said it would have been the proper ideological label for him all along - this begs the question of the degree of anti-Semitism in his ideology at any given time..$^{15}$

The relationship between National Socialism and the labor movement in the 1930 s has been the subject of several studies, naturally focusing on the German case. The similarities are in many ways those focused on by Lundberg: similarities in rhetoric and a large blue-collar membership. ${ }^{16}$ However, research on the relationship between National Socialism in the 1930s and the New Left in the 196os (the end point in Lindholm's conversion) is scarce. There is Götz Aly's Unser Kampf, a provocative piece about the similarities between the National Socialist movement of the 1930 and the German student protests of the 1960s, but while anti-individualism and activism are his points of comparison, Aly is not primarily concerned with ideological analysis. ${ }^{17}$ However, Aly does

Autocracy (Cambridge, Mass: Harvard University Press, 1956). For the historiography of the concept, see Abbott Gleason, Totalitarianism: Inner History of the Cold War (New York: Oxford University Press, 1995).

13 Kunkeler, 'The Evolution of Swedish Fascism,' 379; Wolfgang Wippermann, Faschismustheorien:Die Entwicklung der Diskussion von den Anfängen bis heute (Darmstadt: Wiss. Buchges., 1997), 11-57; Jane Caplan, 'The Historiography of National Socialism,' in Companion to Historiography, ed. Michael Bentley (London: Routledge, 2006), 545-590.

14 William I. Brustein, Roots of Hate: Anti-Semitism in Europe Before the Holocaust (Cambridge: Cambridge University Press, 2003), 327; Renzo de Felice, The Jews in Fascist Italy: A History (New York: Enigma Books, 2001), Robert. O. Paxton, The Anatomy of Fascism (London: Penguin Books, 2005), 9, 166.

15 See RA, SE/RA/720834, manuscript used in interview 1981, 22.

16 Max Kele, Workers and Nazis: National Socialist appeals to German Labor 1919-1933 (Chapel Hill: The University of North Carolina Press, 1972); Conan Fischer, The German Communists and the Rise of Nazism (Basingstoke: Macmillan, 1991); Conan Fischer, ed., The Rise of National Socialism and the Working Classes in Weimar Germany (Providence, R.I.: Berghahn Books, 1996); Detlef Mühlberger, The Social Bases of Nazism, 1919-1933 (New York: Cambridge University Press, 2003).

17 Götz Aly, Unser Kampf, 1968-Ein irritierter Blick zurück (Frankfurt am Main: Fischer, 2008). 
touch on another key aspect of politics, namely esthetics and rituals. The way the individual was transformed into nothing but a part of the movement, and how this was communicated in political ritual such as (protest) marches and speech choirs, may prove important in understanding Lindholm's conversion too. 18

Something should also be said about the relationship between National Socialism and state interventionism such as the New Deal in the US or Social Democratic policies in Sweden. Wolfgang Schivelbusch's Entfernte Verwandtschaft, about the similarities between Mussolini's, Hitler's, and Roosevelt's political projects, can be mentioned here. To solve the economic crises of the $1920 \mathrm{~s}$ and early 1930s, each of these leaders started large-scale infrastructure projects in order to accelerate social transformation and rapid modernizationprocesses that were in many ways similar in the three countries, Schivelbusch argues. ${ }^{19}$ However, though the processes may have been the same, it does not mean the ideologies were. Norbert Götz compares the aspiration to create a German Volksgemeinschaft to another interventionist project, the Swedish social-democratic folkhem, acknowledging that both were grounded in social conservatism and hopes for a national community built on solidarity and belongingness, but finding two important differences between the two: while Volksgeimenschaft demanded complete submission to the state by the individual, this was never how the Swedish folkhem was envisaged. Götz also notes that the end point of the Swedish concept was a provisional utopia, while the Volksgemeinschaft was used far more dogmatically. ${ }^{20}$

In distinguishing between the German and Swedish concepts, Götz's echoes Kunkeler's argument about the significance of the Swedish context. Here it matters that the concept of folkhemmet can be traced back to one source, the conservative political scientist Rudolf Kjellén. Kjellén is interesting since he elaborated on the concept of National Socialism, including the workers in his picture of the nation, but with no marked anti-Semitic tendencies. ${ }^{21}$ Just as the discussion of the differences between Italian Fascism and German National

18 See Ingemar Carlsson \& Arne Ruth, Samhället som teater: Estetik och politik $i$ Tredje riket (Stockholm: Liber, 1983); George L. Mosse, Masses and Man: Nationalist and Fascist Perceptions of Reality (Detroit: Wayne State Univ. Press, 1987).

19 Wolfgang Schivelbusch, Entfernte Verwandtschaft: Faschismus, Nationalsozialismus, New Deal 1933-1939 (Munich: Hanser, 2005).

$20 \quad$ Norbert Götz, Ungleiche Geschwister: Die Konstruktion von nationalsozialistischer Volksgemeinschaft und schwedishem Volksheim (Baden-Baden: Nomos, 2001).

21 See Bert Edström, Ragnar Björk and Thomas Lundén, ed., Rudolf Kjellén: Geopolitiken och konservatismen (Stockholm: Hjalmarson \& Högberg, 2014); Wärenstam, Fascismen och nazismen i Sverige 1920-1940, 14. 
Socialism can be helpful, so Kjellén's ideas may indicate what to look for when judging whether Lindholm's ideas were 'Swedish' or 'German', and the extent to which Lindholm's ideas were anti-Semitic in different periods.

Sven Olov Lindholm's ideological conversion will be analyzed here along lines inspired by the political theorist Michael Freeden. Freeden's proposes that any ideology can be seen as a semantic field containing a number of essentially contestable concepts. Some are core concepts fundamental to the ideology, whereas some concepts are peripheral. Since all concepts are essentially contestable, Freeden also suggests a category of adjacent concepts, which contribute to the definition of the core concepts. In liberalism, for example, 'liberty' is a core concept, and 'free market' is adjacent, whereas 'nation' is peripheral. 'Liberty' may be regarded as a core concept in socialism too, but there it is supported by other adjacent concepts, thus giving a new meaning to the core concept.

Freeden's approach is useful in this particular case for two reasons: it offers a way of analyzing the inner logic of an ideology, with concepts not seen as independent entities to be ticked off a list, but as interdependent parts of a more or less coherent body of ideas; and it provides a tool for analyzing ideological change, for concepts may 'travel' from core to periphery or the other way around, gradually transforming an ideology into something quite different. When studying an ideological conversion, as in this case, this is a very useful approach. ${ }^{22}$ The core cluster of an ideology can be identified using two selective principles: how frequently the subsets occur in the sources, and how interdependent they are. These principles are equally important. The core cluster, though, is the most aggregated level, and may conceal other concepts or conceptual themes that define the core.

The outline of this article is based on six core concepts, or core themes, in the writings of Sven Olov Lindholm-anti-Semitism, anti-capitalism,

22 Michael Freeden, Ideologies and political theory: A conceptual approach (Oxford: OuP, 2008). There are two possible disadvantages of the methodological approach. Firstly, Freeden argues that an ideology cannot be defined entirely by negation, since a negation, like anti-capitalism, has many meanings and possible ideological conclusions (page 67). Much of the core cluster is defined this way, I would argue. When focusing on ideological conversion, the ambiguity of a negation may be crucial though, as it gives the agent (in this case Lindholm) ideological continuity (page 398). Secondly, there is the question of what a concept is. Typically, Freeden uses 'condensed' concepts such as 'liberty' and 'justice', and not the 'extended' concepts I sometimes elect to use. Freeden is not rigid on this point, however, and uses several 'conceptual themes', as he calls them - themes that may encompass something larger than a concept, such as 'valued preservation of the integrity of nature' or 'implementation of qualitative human lifestyles' (page 425, 527). 
anti-imperialism, anti-materialism, the idealization of the worker, and Nazi Germany as the worker's state - of which the latter two are 'conceptual themes' in Freeden's terminology. Some of these themes are generally intuitive; some are not. They are all extracted from a careful reading of Lindholm's personal archives, ${ }^{23}$ pamphlets or printed speeches, and all of the articles signed by him issued from the party press: three different types of sources. ${ }^{24}$ Even though the sources are extensive and diverse, it must be said that — as in every biographical case study - the results are not necessarily representative of any larger entity (not even his own party), and are impossible to generalize from. With Lindholm's prominent position in mind, not to mention his extraordinary conversion, it is only reasonable to study him in his own right.

The following analysis has two main sections. In the first, the suggested subsets of Lindholm's core cluster and their intersection are analyzed. In the second, I discuss what remained of this core in the post-war era. Lindholm's conversion will be analyzed mainly as a two-part process, although a few nuances will be noted, especially when it comes to anti-Semitism. This diachronic assessment helps illustrate the coherence of the cluster, as suggested by Freeden.

\section{1 \\ Anti-Semitism}

During almost the entire SFKO-NSAP-SSS era, anti-Semitism was a cornerstone of Sven Olov Lindholm's writings. This should come as no great surprise. However, the emergence of anti-Semitism and the organization of its subsets may reveal less conventional patterns.

The first thing to note is that there is no hint of anti-Semitism evident in what seems to have been Lindholm's first article, 'Grunddragen hos fascismen' [The main traits of fascism], published in Spöknippet [The Fasces] in

23 One part of the archival collections is interviews by Ingmar Carlsson at the National Archives of Sweden in 1980-1981. Lindholm was always sent the questions in advance, and prepared a manuscript he used during the interviews, usually following it closely. For accuracy, I have used this manuscript as the source. See Ingmar Carlsson's comment on the manuscript, RA, SE/RA/720834, manuscript used in interview 1981, 1.

24 When it comes to pamphlets and printed speeches, all examples listed in the joint catalogue of the Swedish academic and research libraries, Libris, were included, although they are not all cited here. For the party press, the following newspapers have been studied: Spöknippet (1926-1930), Nationalsocialisten (1930), Vår Kamp (1930-1933), Den Svenske Nationalsocialisten (1933-1938), Den Svenske Folksocialisten (1939-1950), and Nationell Socialism (1935-1938). 
December 1926. ${ }^{25}$ Although not a book review, it made plain that his understanding of the concept of 'fascism' was based on a book written by the Italian Fascist Pietro Gorgolini. ${ }^{26}$ It shows that Lindholm at this early stage was picking the cornerstones of the ideology to which he subscribed. Given the relation between National Socialism and Fascism, and the importance of international influences, this is crucial.

In his article, Lindholm elaborated on the prominent role of the nation, the need for social reform that focused on the proletariat, and how deeply interconnected these themes were. While the mixture of his arguments was not always coherent, one thing can be certain: there is no polemic against Jews. This lends some credence to the argument that his ideological inspiration at this early stage was exclusively Italian. When Lindholm entered politics in May 1926, one of his first contacts with the right-wing was the wildly anti-Semitic paper Nationen [The Nation], edited by Elof Ericsson. In interviews in the early 1980s, Lindholm said that the anti-Semitism of this publication was one of the reasons behind the rupture between Ericsson and the leaders of the SFKO. To some degree, this is confirmed by previous research as well. ${ }^{27}$ Gradually this changed, and after attending a Nuremberg rally in 1929 his antagonism towards Jews was an irrefutable core value. In fact, the lack of anti-Semitism then was used as an argument against (Italian) Fascism, which was criticized for trying to address society's problems, but not their origin-the Jews. ${ }^{28}$

In Nuremberg he met Gregor Strasser and Gottfried Feder. These acquaintances seem to have been an important influence on Lindholm, and he met them on several occasions after this first contact. Typically, Strasser and Feder have been regarded as advocates of a left-leaning National Socialism, and in his diary Lindholm stated that he and Strasser 'totally agreed' on the need for the nationalization of large companies. ${ }^{29}$ This was a kind of National Socialism that appealed to Lindholm. From his account of the rally, published in Spöknippet, it is clear he was also impressed by the overall esthetic of the German movement-all those marches and banners (especially the use of the Blutfahne from the Beer Hall Putsch in 1923) $\cdot{ }^{30}$ However, 1929 also marked a

25 Sven Olov Lindholm, 'Grunddragen hos fascismen,' Spöknippet, December 11, 1926.

26 Pietro Gorgolini, Den italienska fascismen (Uppsala: Almqvist \& Wiksell, 1924).

27 RA, SE/RA/720834, manuscript used in interview 1981, 17, Berggren 1999, 165-167.

28 See 'Nationalsocialism och fascism,' Vår kamp, August 15, 1931; 'Med arbetarna mot marxismen,' Vår kamp, October 15, 1931.

29 RA, SE/RA/720834, Sven Olov Lindholm's diary, August 2, 1929, December 2, 1932, December 6, 1932 .

30 Articles about the rally in Nuremberg were published in Spöknippet, August 14, August 21, August 28, and September 4, 1929. 
sudden increase in attacks on Jews in his writings, indicating a transfer of German ideas to the Swedish 'National Socialists', which was the ideological label Lindholm now started to use.

The inner logic of the anti-Semitic subsets in Lindholm's thinking from this time and onwards should be noted. Wherever anti-Semitism was adopted, almost every opposing idea or institution was labeled Jewish. Most prominently, democracy, Marxism and/or Bolshevism, and capitalism were denoted as Jewish. At an early stage these aspects of anti-Semitism came together in what at first glance were incoherent patterns; however, in the wake of the Nuremberg rally, a more clear-cut ideology was formed in which the three aforementioned Jewish phenomena were put into a more coherent framework. The starting point of this opposition was the idea that democracy was a threat to national solidarity and unity, since different interest groups within the nation were in conflict and a simple majority could outdo the minority. Democracy could not overcome the differences within the nation. This, in turn, meant that the problem of democracy was the same as the problem of the class struggle was to Marxism: it threatened to tear the nation apart. Lindholm was aware that Karl Marx was Jewish, but Marxism's 'Jewishness' was not the main concern, at least according to Lindholm. Rather, it was that widespread social conflict within the nation would pave the way for exploitation at the hands of international Jewish capitalists. In this sense, the Jewish capitalist was the most prominent of the anti-Semitic stereotypes, and it tended to incorporate other anti-Semitic elements. ${ }^{31}$ This order of priority between the different stereotypes was also confirmed when Lindholm stated that the Jewish question 'cannot be reduced to a matter of population policy. It is Jewish financial power... that needs to be stopped. ${ }^{32}$ Democrats unwilling to tackle this financial power were bound to 'float like cork pillows', at the mercy of the whims of Jewish bankers and industrialists. ${ }^{33}$ This also leads us back to the reason why Italian Fascism was criticized for not dealing with the fundamental problem: social reform might reduce destitution, but would only ease the symptoms of capitalism instead of dealing with the profiteers in the system-the Jews.

31 Sven Olov Lindholm, Den röda offensiven (Gothenburg, 1937), 12; Sverige till salu (Gothenburg, 1937), 5, 13; 'Bilda åtalsfond! Front mot bankjudarna,' Den Svenske Nationalsocialisten, July 12, 1934; 'Masslögnen: Marxisttidningarna inympa det kapitalistiska tänkandet i massorna,' Den Svenske Nationalsocialisten, September 25, 1935; 'Det nya kampåret,' Den Svenske Nationalsocialisten, January 5, 1935; 'Skall tredje mans "rätt" bli största orätt?' Den Svenske Nationalsocialisten, May 1, 1935; 'Demokratin är kapitalismens livsluft,' Den Svenske Folksocialisten, August 19, 1939.

32 Sven Olov Lindholm, 'Nationella partier', Den Svenske Folksocialisten, November 25, 1939.

33 Sven Olov Lindholm, Svensk frihetskamp (Stockholm: NS Press, 1943), 115. 
In Lindholm's writings, anti-capitalism was in this sense the primary cause, and it remained so throughout the party years. In his early writings, polemics against capitalist exploitation can be found stripped of their anti-Semitic superposition. This was the case in his article in Spöknippet in 1926. Anticapitalism was of course an important ideological feature in his second political awakening too, albeit in a somewhat convoluted fashion.

As seen, anti-capitalism was closely interconnected to the core concept of anti-Semitism. Separating the essentials from the non-essentials was difficult in this case, but most of the time meaningless, since 'Jew' and 'capitalist exploiter' were often regarded as synonymous. The crucial aspect, then, was that Jews - both implicitly and explicitly — were defined as a group of capitalists. This led to a racial category being defined as a social category, in a manner that was strikingly similar to the bourgeoisie in Marxism. Something similar applied to 'Swedes'. In the same way that Jews were seen as capitalists, 'Swedes' or 'Scandinavians' were seen as workers. Even though a 'worker' in Lindholm's thinking was a broader concept than in Marxist socialism, its definition still provided the prerequisites of a special kind of class struggle along ethnic linessomething that was plain from Lindholm's own version of The Internationale, with altered lyrics and Pierre De Geyter's well-known melody. In it, Lindholm spoke of how the 'Swedish army of workers' was going to 'throw off the yoke of slavery' forced on them by 'sovereigns of capital' and 'Jewish hands' ${ }^{34}$ Elsewhere, his writing also confirmed this idea of a principal antagonism between 'the Nordic worker' and Jewish capitalists. ${ }^{35}$

This Marxist trait in an outspokenly anti-Marxist ideology was of course contradictory, but was also confirmed by what was at heart of the conflict: the values produced in productive labor by the worker, values threatened by exploitation at the hands of Jewish capitalists, or what Marx had as surplus value. The idea is that income may be earned in two different ways: either by creating value or by exploiting value produced by someone else. The first way is good;

34 Sven Olov Lindholm, Sånger och dikter (Gothenburg, 1934), 6-7. This song, 'Arbetarnationalen', was republished several times in the party press and used in the so-called 'battle of songs' against communist opponents during party meetings. Lyrics republished in Var kamp, January 1 \& March 15, 1932.

35 Sven Olov Lindholm, Den röda offensiven (Gothenburg, 1937), 18; Sven Olov Lindholm, 'Rasen inför ödestimman,' Den Svenske Nationalsocialisten, March 1, 1933. 
the second is morally wrong. In the trade union founded by Lindholm's party, Sveriges Fackliga Kamporganisation [sF KO; Sweden's Combat Union], this argument was condensed in the motto 'The fruits of labor to the people of labor', a motto Lindholm sometimes used himself. ${ }^{36}$ The idea that money should be earned by exposing money to risk, an argument frequently proposed in modern capitalism, was non-existent.

Apart from exploiting the surplus value of productive labor, capitalism was opposed for other reasons. Yet one example, similar to what was often advocated by the Marxist labor movement, was that capitalism tends to create a state within the state. Once again, the control of power was Lindholm's focus. This was an argument also used against liberal democracy per se: as long as capitalism existed, true democracy could never be attained. The democratic system had to be attacked, according to Lindholm, not because it had given power to the people, but because democracy had degenerated into plutocracy, leading him to conclude that the power of the state must be total:

The condition for a regime according to our ideas must be capability, forethought, and an honest ambition to realize what is best for the people. But the condition is also to obtain the people's trust - not the trust of the Jewish interests, the newspaper corporations, or the union men. The fact that the power of the state shall be 'total' actually means that everything shall concentrate on one common goal, and that the interests of capital are controlled by the government - i.e. there cannot be a 'state within the state'. Those who want can of course refer to this as totalism or dictatorship, but it is actually nothing but socialism. ${ }^{37}$

It would be fair to assume that these Marxist traits provided for a smooth ideological transition in the sixties and seventies. This assumption is not borne out, however. Anti-capitalism was an important feature of the ideological message in the sixties too, but tended now to focus on the global redistribution of wealth as a vital necessity for mankind rather than on the conflict between

36 See Sven Olov Lindholm, 'Nationalsocialismen en bekännelse till folket,' Den Svenske Nationalsocialisten, January 9, 1935; Lundberg, En idé större än döden, 66.

37 Lindholm, Svensk frihetskamp, 38: 'Villkoret för en regim enligt våra idéer måste vara dugligheten, förutseendet och den ärliga viljan att genomföra vad som är folkets bästa. Men villkoret är också folkets förtroende—icke judeintressenas, tidningsbolagens och LOherrarnas. Att statsmakten skall vara "total" innebär i själva verket att allting skall inriktas på ett gemensamt mål samt att regeringen har makten också över kapitalintressena—det får m.a.o. ej finnas någon 'stat i staten'. Den som vill kan ju kalla detta för totalism eller diktatur, men i verkligheten är det inget annat än socialismen.' 
racial or social groups. This is an aspect of Lindholm's personal conversion I will return to when analyzing the evolvement of his anti-materialist position.

\section{$3 \quad$ Anti-Imperialism}

The third core concept that can be seen in Sven Olov Lindholm's writings is perhaps not the first thing that comes to mind when speaking of a National Socialist leader: anti-imperialism. This theme was tackled from two different angles. The first used the nation as a point of departure, and stated that national freedom can never be obtained under imperial pressure. Since every nation is fundamentally inviolable, imperialism should be opposed on principle. Lindholm continued to argue this throughout the party years: in his first article in Spöknippet, for example, he stated that a key element in his understanding of the concept of fascism was that 'fascism opposes imperialism, signified by domination of one state over another or one people over another'. ${ }^{38} \mathrm{He}$ returned to this argument several times in the postwar era to defend himself from accusations of collaboration with Nazi Germany.

The second angle on anti-imperialism stemmed from his hatred of Jewish capitalism. Imperialism was for him the result of capitalism, and the Jewish pursuit of world power was in this sense 'imperialism'. The interconnect of anti-Semitism, anti-capitalism, and anti-imperialism illustrates Freeden's argument about the coherency of the core cluster quite well. The idea of imperialism as an immanent feature of capitalism was of course strikingly similar to the ideas Lenin put forward by in his classic Imperialism, the Highest Stage of Capitalism in 1916: the need for profit would hunt big business around the globe, leading to imperialism as a movement. ${ }^{39}$ When Lindholm argued this point, it was often in a form that contrasted the independence of small nations with an aggressive Jewish power that 'is to blame for most wars'. 40 There was an illuminating difference in how the German occupation of Denmark and Norway was treated. Lindholm was clearly opposed to it, seeing it as a classic

38 Sven Olov Lindholm, 'Grunddragen hos fascismen,' Spöknippet, December 11, 1926.

39 Vladimir Lenin, Imperialism, the Highest Stage of Capitalism (Beijing: Foreign Languages Press, 1969 [1916]).

40 Quote from 'Slåss Finland för demokratin?' Den Svenske Folksocialisten, January 27, 1940; see also his 'Alla ha svikit Finland!' Den Svenske Folksocialisten, December 20, 1939; 'Fredsvillkoren,' Den Svenske Folksocialisten, January 6, 1940; 'Försvarsförbund mot Sovjet,' Den Svenske Folksocialisten, March 23, 1940; 'När demokratin "räddade norden"', Den Svenske Folksocialisten, March 16 1940; 'Det nya Europa som England vill ha det,' Den Svenske Folksocialisten, December 12, 1942. 
example of how a 'national popular rising shall not be realized' ${ }^{11}$ But since he believed Nazi Germany to be a fundamentally socialist state that had thrown off the capitalist yoke, this aggression was not counted imperialism; rather, the occupation was seen as response to the capitalist states' determination to encircle the new progressive state of Germany. The main target of this critique was the UK-a prime example of a capitalist state accused of imperialism, and often regarded as an agent of Jewish interests. As acceptance of the Quisling regime in Norway gradually increased, an important factor was the Norwegian exile government's location in the UK as the guest of the Jewish-dependent British government. Such a Jewish-dependent government would never be able to reestablish a free Norway. ${ }^{42}$ In other words, Lindholm's conception of the world, when stripped of its anti-Semitic veneer, was in many ways similar to the Comintern's in the thirties: socialism was always opposed to imperialism, and was often exposed to imperialist aggression from the agents of capitalism whenever their interests were threatened. ${ }^{43}$

\section{4}

\section{Anti-Materialism}

The fourth core concept in Lindholm's writings from his time as a Nazi leader was anti-materialism. It could also be labeled an all-embracing criticism of modernity, given his frequent caustic remarks about the kind of progress that achieved nothing, and turned people into egocentric, indolent, pleasure-seeking creatures intent on nothing but filling their pockets with cash and their homes with material goods. He opposed urban culture, and said the culture of the machines reduced every man to nothing more than a factor in production. The role model for the reborn, idealistic, authentic human was instead the farmer-or at least a man who knew how to cultivate the soil instead of exploiting it. ${ }^{44}$ Seemingly, this focus on the farmer as the ultimate authentic

41 Sven Olov Lindholm, 'För sent!' Den Svenske Folksocialisten, April 13, 1940.

42 Sven Olov Lindholm, 'Nordens marodörer', Den Svenske Folksocialisten, October 10, 1942; see 'Angreppen mot Norge,' Den Svenske Folksocialisten, January 10, 1942; 'Norges väg,' Den Svenske Folksocialisten, February 7, 1942.

43 See Wolfgang Wippermann, Fascismustheorien: Die Entwicklung der Diskussion von den Anfängen bis heute (Darmstadt: Wissenschaftliche Buchgesellshaft, 1997), 58; Jane Caplan, 'The Historiography of National Socialism,' in Companion to Historiography, ed. Michael Bentley (London: Routledge, 2006), 550.

44 Among the numerous examples are Sven Olov Lindholm, 'Alltid för sent!' Den Svenske Folksocialisten, March 28, 1942; 'Bonden och Svensksocialismen,' Den Svenske Folksocialisten, August 26, 1939; 'Den eviga freden,' Den Svenske Folksocialisten, January 2, 1943, 
human conflicts with the idealization of the worker, another core aspect of Lindholm's ideology. One possible way of understanding this is that Lindholm's definition of work is much wider. Work for him was a process of creation, a definition that potentially encompassed many different assignments as long as they are opposed to the exploitation of Jewish capitalism. ${ }^{45}$ There may however still be a bit of incoherence that is worthy of note.

The anti-materialist attack on modernity revealed an ambition to transform society as a whole into something better, but the starting point was always the individual. Society had to be renewed from below. In the same way as a true community can never be built without social justice for those of few means, social justice can never be obtained if people are not transformed from within. In one of his few contributions to his movement's theoretical journal Nationell Socialism [National Socialism] Lindholm characterized this new man as a less egocentric, more altruistic person, who would not fail in his public duties:

The National Socialists are humble working men from the farthest ranks of the people; we strive for prosperity, to build a home and find a path through life-on these matters we are all the same. But we want something else besides - to revolutionize society and give it a new life form. Then our first task is to revolutionize the people, not just in words but by good example, telling the Swedes: one does not live to eat and become fat, but to do one's duty, and this fulfillment of one's duty applies to everyone. ${ }^{46}$

It should be noted that the ideal of creating a man with a new moral compass was closely connected to the theme of anti-capitalism. In fact, anti-capitalism

'Bondenöd är folknöd,' Den Svenske Folksocialisten, June 19, 1943; 'Rättsmedvetandet upplöses,' Den Svenske Folksocialisten, March 25, 1944; 'Eken dör,' Den Svenske Folksocialisten, May 13, 1944; 'Är folket till för industrierna: Eller industrierna för folket?' Den Svenske Folksocialisten, March 16, 1946.

45 This distinction between creation and exploitation is of great importance in Sven Olov Lindholm, 'Arbetaren: Den kommande tidens gestalt,' Den Svenske Nationalsocialisten, January 251933 .

46 Sven Olov Lindholm, 'En ny livsstil,' Nationell Socialism, 7-8, 1936: 'Nationalsocialisterna äro enkla, arbetande människor ur folkets djupa led, vi sträva också efter välstånd, vilja bilda eget hem och bryta oss en bana i livet—i det fallet äro alla lika. Men vi vilja dessutom något annat—revolutionera samhället och giva det en ny livsform. Då gäller vår första uppgift att revolutionera människorna, att ej blott med ord utan även med föredöme säga till svenskarna: man lever inte för äta och göda sig utan för att göra sin plikt, och all pliktuppfyllelse gäller andra.' 
tended to merge with anti-materialism, forming a broad front against consumerism. In many ways, this anti-consumerism was similar to Lindholm's anticapitalism. In both, the plutocracy of contemporary society was opposed, as was its spin-off, fully fledged hedonism. An important difference, though, was that Lindholm's anti-consumerist message was often expressed with little or no hint of anti-Semitism. ${ }^{47}$ Where the desire to consume was superseded by new, less material ambitions, this would of course affect Jewish profits and consequently the backbone of Jewish power; yet, more often than not, this part of Lindholm's ideological message did not include any anti-Semitic stereotypes.

It should also be noted that this anti-materialist message contradicted important elements of what had been regarded as the root cause of the conflict between Swedish workers and Jewish capitalists - the surplus value of production. This can be seen in the quote above in the tension between 'prosperity' and his attack on gluttony.

\section{$5 \quad$ The Idealization of the Worker}

The fifth core theme turned on the antagonism between Jewish capitalist and Swedish worker, where the first was demonized and the latter idealized. This might be thought inherent to anti-capitalism, but it can also be seen as a core theme in its own right.

The ambition to free working heroes from the burden of work can be noted in Lindholm's early years as a Fascist. At that point, he frequently published front-page poems in Spöknippet, often focusing on the labor movement as a false advocate of working people's interests and these humble, hard-working men and women's struggle for decent lives. In these poems, his critique of plutocracy and exploitation sometimes meets his critique of the machines. In one, 'Swedish heroes', the soul and limbs are said to wither away. ${ }^{48}$ The working heroes are killed; they are chewed up by the machinery of industrialism. ${ }^{49}$ These

\footnotetext{
47 Sven Olov Lindholm, 'Folkgemenskap eller individuell högfärd,' Den Svenske Folksocialisten, March 8, 1941; Sven Olov Lindholm, 'Är Sverige redo?’ Den Svenske Folksocialisten, June 17,1944 .

48 Sven Olov Lindholm, 'Svenska hjältar', Spöknippet, January 22, 1930.

49 For the idea of 'a machine that minces the flesh and bones' of the worker, and its use by the labor movement of Sweden in the early twentieth century, see Emma Hilborn, Världar i brand (Lund: Agerings, 2014), 104-115. See Kunkeler, 'Sven Olov Lindholm and the Literary Inspirations of Swedish Fascism.; Vulovic, Reform eller revolt, 89; RA, SE/RA/720834, manuscript used in interview 1981, 104, for comments on Lindholm's use and interest in Viktor Rydberg and his poem about Grotte.
} 
themes seem to contradict, or at least modify, Victor Lundberg's assessment mentioned in the beginning of this article. ${ }^{50}$

The most striking example of this tendency is the article "The Worker: The Figure of the Coming Age', printed on the front page of the first issue of his party's own newspaper. ${ }^{51}$ It was republished several times, and as a précis (retitled 'The nobility of labor') was one of Lindholm's few contributions to the journal Nationell Socialism. ${ }^{2}$ The frequent reprints give the impression of an important ideological document. It certainly bears out many of the points made here. The most illuminating passage concerning idealization is probably this:

To us as National Socialists, the Swedish worker stands out as the genius of the coming age, not the sharks of the big corporations! He is the symbol of creative man and a promising symbol of our people's will to live and believe in the future. The figure of the worker shall characterize all people who want to live free and fortunate. Through the smoke of grimy factories his tall, blond figure can be seen, with his Nordic Viking temperament, happy to struggle, ready to struggle. He is no longer a slave of the machines-in the land of the coming age, production is not about generating profit, work is done for its own sake. To employ and provide for-not to exploit or to speculate $!^{53}$

Just as Lindholm's ideological message was at the very least implicitly Marxist when he wrote about surplus value, this passage touches upon another strikingly Marxist idea. In his book The German Ideology, Karl Marx stated that when general production is regulated by society, every man will be able to 'do one thing today and another tomorrow, to hunt in the morning, to fish

50 Lundberg, En idé större än döden.

$5^{1}$ Sven Olov Lindholm, 'Arbetaren: Den kommande tidens gestalt,' Den Svenske Nationalsocialisten, January 25, 1933, republished in Den Svenske Nationalsocialisten, January 12, 1935, and in Den Svenske Folksocialisten, April 4, 1942 and October 23, 1943.

$5^{2}$ Sven Olov Lindholm, 'Arbetets adel,' Nationell Socialism, 9, 1936.

53 Sven Olov Lindholm, 'Arbetaren: Den kommande tidens gestalt', Den Svenske Nationalsocialisten, January 25, 1933: 'Så står för oss nationalsocialister icke bolagshajen utan den svenske arbetaren som den kommande tidens genius! Han är symbolen för den skapande människan och han är en löftesrik kampsymbol för vårt folks livsvilja och framtidstro. Arbetarens gestalt skall sätta sin prägel på varje folk som vill leva fritt och lyckligt. Ur sotiga fabrikskvarter skönjes det genom röken hans ljusa resliga gestalt med nordiskt vikingalynne, kampglad, kampberedd. Han är inte längre slav under maskinerna—ty i framtidslandet produceras det icke för vinst, icke för profit, utan för arbetets egen skull. För att sysselsätta och försörja—inte för att utnyttja och spekulera!' 
in the afternoon, rear cattle in the evening, criticize after dinner, just as I have in mind, without ever becoming hunter, fisherman, shepherd or critic'.54 This famous quote has often been seen as a utopian vision of times to come-a society in which every man is freed of the burden of productive labor and may do whatever he likes. Even if there is some tension in Lindholm's article between the ambition to ensure employment on the one hand and to 'conduct work for its own sake' on the other, it remains yet another striking similarity between the thoughts of Marx and Lindholm.

Even if the 'worker' is held in high esteem, in Lindholm's thinking this was still a much broader concept than the labor movement's 'worker'. 'Everyone who creates values - spiritual or material-is a worker', as Lindholm wrote. ${ }^{55}$ This applied to white-collar workers just as much as manual workers. A crucial difference between the definitions was that Lindholm had no objections in principal to people owning the means of production, as long as it did not exploit the value of other's work. The ideological component dealing with the 'surplus value of production' was extended to more sections of the population, but with one thing in common: unlike Jewish capitalists they should not live on unearned income achieved by charging interest or stock market speculation. This distinction also goes some way to explaining Lindholm's interest in farming.

\section{Nazi Germany as the Workers' State}

Most of these themes came together in Lindholm's views on the Third Reich. As said, after the war Lindholm was often eager to distance himself from German actions and foreign policies during the war. This to some extent had been the case even during the war, as his response to the Norwegian occupation indicated. When it comes to Germany's domestic policies, however, quite the opposite was true. Here, Lindholm stated openly that 'Hitler has given socialism to the masses', and went on to play up on his 'masterpiece of domestic politics.' ${ }^{66}$ The socialist catchwords of the men he met in Nuremberg in 1929, Gregor Strasser and Gottfried Feder, had been transformed into real politics,

54 Karl Marx, The German Ideology [1845-1846], Marxists.org, accessed May 16, 2017, https:// www.marxists.org/archive/marx/works/1845/german-ideology/choia.htm.

55 Sven Olov Lindholm, 'Arbetaren: Den kommande tidens gestalt,' Den Svenske Nationalsocialisten, January 25, 1933.

56 Sven Olov Lindholm, 'sss intet Quislingparti,' Den Svenske Folksocialisten, September 28, 1940; 'Tre till finalen,' Den Svenske Folksocialisten, March 20, 1941. 
and his thoughts on the ideological divisions between Strasser and Hitler were either reserved for his diary or noted afterwards ${ }^{57}$; he is silent on the subject in the contemporary press.

His main idea seems to have been that Hitler's socialism provoked an aggressive reaction from global Jewish interests, who were threatened by the emancipatory achievements of the newborn German state. The Second World War was caused by this aggressive reaction, for Jewish imperialism (built on financial interests) had turned its weapons on socialist Germany, forcing the fundamentally peace-loving Führer into military action to avoid encirclement and defeat. The repercussions of the Treaty of Versailles were plain in this argument. ${ }^{58}$ The fact that Jews were in the main seen as a social category, a bourgeoisie, contributed to a mixture of seemingly incompatible ideas: on the one hand was a Leninist analysis of imperialism as an immanent feature of capitalism; on the other was the German Dolchstoßlegende, the stab-in-theback myth. In both cases, world Jewry had attacked the German people as they strove for decency and righteousness.

A pronounced example of this interpretive framework is Lindholm's assessment of the League of Nations-'the League of Guns' or 'League of War in Geneva' as he called it. Whenever the origins of this organization were described, the peace terms of Versailles were given as the starting point. It was implied that under these terms the German people were subjugated by the Jews, especially as the potential causes of war had also been included-for fear that the dominant position of the Jewish aggressor might be threatened. The centerpiece had been the League of Nations, defined as a government of all governments, whose task was to 'guide all states to take a direction pleasing to Jewish interests, and to watch over the security of the economic International. When the people of Germany at last rallied to the Swastika and started their country's liberation from capitalism and Jewish dependence, the peace terms struck back against Germany, just as anticipated. In sum, this series of events was seen as 'a preliminary exercise in the coming imperialist war to secure Jewish interests and vindictiveness'. ${ }^{99}$ Based on this worldview, Lindholm also gathered a list of signatures against the League of Nations, and he personally delivered the names to the Swedish king. ${ }^{60}$

57 RA, SE/RA/720834, Sven Olov Lindholm's diary, December 6, 1932 \& July 5, 1934; Sven Olov Lindholm, Döm ingen ohörd (Lund, 1968), 21.

$5^{8}$ Sven Olov Lindholm, 'Hitlers första tio år,' Den Svenske Folksocialisten, February 6, 1943; Sven Olov Lindholm, Svenskt eller osvenskt (Stockholm, 1941), 28-29.

59 Sven Olov Lindholm, 'Judarna vill krig!' Den Svenske Nationalsocialisten, October 2, 1935.

6o RA, SE/RA/720834, Sven Olov Lindholm's diary, May 24, 1938. 
Lindholm continued to hold many of Hitler's welfare policies in high esteem after the war. However, the first signs that he was modifying his assessment were there in his obituary of the Führer. In it Hitler is still idealized, but according to Lindholm 'there were many minor officials who tore down Hitler's achievements politically as well as morally.' ${ }^{\prime 1}$ This statement may seem apologetic; that was certainly Lindholm's intention. Yet in this passage he interprets wartime events along functionalist lines, stating that the bureaucratic structure of the Nazi state was far too complex for Hitler to control, and in that sense he should be rated a 'weak dictator', to paraphrase the functionalist historian Hans Mommsen. ${ }^{62}$ Hitler's responsibility for the atrocities of the Nazi state was seen as limited or non-existent. If nothing else, this revealed the traits of what may be regarded as an ideological learning process. This process had started with denial and relativism in the face of the crimes of the Nazi era, which were usually dismissed as the lies of the Jewish press. ${ }^{63}$ During the second phase, he acknowledged their existence, at least to some extent, but gave a functionalist explanation, as above. During the third phase, the intentionalist interpretation prevailed. Overwhelming evidence, reinforced by private conversations with old German friends such as Max Pferdekämper, Hans Lange, and Rudolf Otto, drove this reevaluation. ${ }^{64}$ Even if the atrocities were seen as a kind of derailment of a 'true' National Socialism, there was no longer any rational point to defining oneself as a National Socialist. As a consequence, Lindholm cast about for a new ideological home, something he found in the broad New Left of the sixties and seventies. Put this way, his reevaluation of the Nazi state and its achievements can be seen as the driving force in Lindholm's transformation.

The end of the war in Europe in May 1945 for most people put a definitive end to the attraction of National Socialism. The atrocities of the Third Reich had been revealed. Many of its leading figures were executed or jailed. Suspicions that Lindholm's party had received financial support from Germany put

\footnotetext{
61 Sven Olov Lindholm, 'Hitler är död,' Den Svenske Folksocialisten, May 4, 1945.

62 Quoted in Ian Kershaw, The Nazi Dictatorship (London: Arnold, 2000), 70.

63 See Sven Olov Lindholm, Döm ingen ohörd! (Stockholm, 1945), 8.

64 RA, SE/RA/720834, manuscript used in interview 1981, 36.
} 
Lindholm in court in Sweden in 1948, accused of collaboration. No evidence was found, however. ${ }^{65}$

Its base having dwindled to almost nothing, the party was dissolved in 1950. The same year Lindholm remarried. Two years later a daughter was born, and he and his second wife, Vera, moved to a small house in Rönninge, Salem, a suburb outside Stockholm. After a period of unemployment, an old friend from the party years called Sven Hedengren helped him find a job at Monotype, where he started by hiring and selling printing types. From his notes, he seems to have enjoyed it, apart from the fact that his colleagues were 'politically unconscious' and incapable of discussing anything but cars and food. ${ }^{66}$ It seems to have been a happy period for him, but reassessing his political ideas and the ambition 'to always have something important to struggle for' brought him to a new political awakening at the end of the sixties. ${ }^{67} \mathrm{He}$ started to protest the American aggression in Vietnam, nuclear power, and war. The question is what - if anything - remained from his original ideological core?

Unsurprisingly, anti-Semitism lost much of its importance after the war. In interviews and writings from the sixties and onwards, Lindholm could scarcely bring himself to acknowledge that there had been any anti-Semitism in the party at all, but when he did, he was again eager to emphasize the dimension of power. The ambition, he said, had been to counteract what was then regarded as the 'massive' Jewish influence on economics and culture, and not to persecute an entire race. He also stressed what he thought of as an important distinction between positive racist policies in favor of the Nordic race, and negative racism against the Jews, leading to their extermination. To Lindholm's mind, his own party should be regarded as 'racist' in the first sense only-in contrast to the German Nazis. ${ }^{68}$ According to Heléne Lööw, who interviewed Lindholm on several occasions in the eighties, he was always unwilling to discuss the role of anti-Semitism in his party. She informed him that the speeches he gave as a party leader were still available in the police archives, and asked if he wanted to see them. He refused. ${ }^{69}$

Anti-capitalism was an important element in Lindholm's ideological message in his second phase too, but tended now to focus on the global redistribution of wealth as a vital necessity for mankind rather than on the conflict between racial or social groups. In this sense, anti-capitalism tended to merge

65 Lööw, Nazismen i Sverige 1924-1979, 41.

66 RA, SE/RA/720834, notes, 'Soldatliv \& Politik,' pt. 2, 57-60.

67 RA, SE/RA/720834, notes, 'Soldatliv \& Politik, pt. 2, 95.

68 RA, SE/RA/720834, manuscript used in interview 1981, 55; Sven Olov Lindholm, Döm ingen ohörd (Lund, 1967), 10.

69 Information given by Heléne Lööw, e-mail to the author October 10, 2018. 
with anti-materialism, forming a broad vision of anti-consumerism as the only way of saving the planet. ${ }^{70}$ The consequence of this was that the surplus value of production was no longer the focus, since production was not necessarily a good thing (production was always a means of exploitation of resources, of which we should to be very careful, Lindholm said). Combined with a sudden lack of anti-Semitic agenda, this meant that the explicit perspective of socioracial conflict was gradually fading. This also hinted at a transformation from what in the thirties had most likely been seen as a variation of conservatism into something that might be called environmentalism.

As anti-Semitism faded away and anti-capitalism was transformed into an all-embracing criticism of modernity, the variant of anti-imperialism that stemmed from the idea of Jewry and big businesses as the propelling forces behind imperialism also tended to fade away. The reason was the interdependence of the themes in the core. The idea that the nation was fundamentally inviolable and that national freedom never could be obtained under imperial pressure can still be found in Lindholm's writings, however. He also used a variation of this argument to defend himself from the accusations of collaboration with Nazi Germany. Following Albert Speer, Lindholm quoted Hitler: nationalism as an idea cannot be exported, for every nation has its own roots and culture, which were the cornerstone of their variations on the national idea. Therefore, Sweden, like every nation, was inviolable. On these grounds alone, collaboration with German troops was out of the question, Lindholm wrote. ${ }^{71}$ In the seventies, he used a variation of this when he spoke out against the Vietnam War. His sympathies lay with the Front National pour la Libération du Sud Viêt Nam, or the Vietcong, which he held to be a national liberation movement of the same type as his Nazi movement in the thirties and forties. ${ }^{72}$ Thinking back to one of the many protest marches, he wrote:

Once-on 1 May 1974-I was entrusted with carrying the banner of the Vasa FNL group from Kungsträdgården to Hötorget [in Stockholm]. We were 12,00o people in this procession of demonstrators. When we entered Kungsgatan, I was struck by the fact that this was the place where my 'own troops' marched 40 years ago, holding banners in the same colorsblue, yellow, red—and I thought of this as very symbolic: at heart, I am

70 Sven Olov Lindholm, Döm ingen ohörd (Lund, 1967), 21-23; Sven Olov Lindholm, Döm ingen ohörd (Lund, 1968), 27-31.

71 RA, SE/RA/720834, Sven Olov Lindholm 'Soldatliv \& Politik, pt. 1 [notes], 18o. Lindholm refers to Albert Speer, Erinnerungen (Berlin: Propyläen Verlag, 1969), 136.

72 Lars Holmström, 'Han var ledare för Sveriges nazister', Aftonbladet, June 6, 1971. 
still driven by the same concepts as then, even though they are expressed differently. ${ }^{73}$

This is illuminating about ideological continuity, but also touches upon the role of esthetics and ritual in a conversion like Lindholm's. He had been impressed by the banners in Nuremberg in 1929, and his emotions were basically the same forty five years later. His remarks confirm what Aly had found, that the importance of ritual was as great in the 1960s as it had been in the 1930 .

Anti-materialism had contradicted important elements of what had been regarded as the root cause of the conflict between Swedish workers and Jewish capitalists - the surplus values of production, and this contradiction began to fade in Lindholm's second ideological phase once the 'fruits of labor' were no longer his focus. This sat well with the broad ideological trends of the new era, for when economic growth was questioned in the sixties and seventies and no longer regarded as natural, the idea of a surplus value was also questioned. Production ceased to be regarded a necessity—rather, it was keeping production at a minimum that was a necessity for mankind. Instead of endeavoring to increase our own prosperity, it was the global redistribution of wealth that mattered, Lindholm wrote in Döm ingen ohörd in $1968 .{ }^{74}$ The exploitation of Swedish workers had been replaced by the exploitation of resources as his chief concern.

When Lindholm found a new ideological home in the late 196os, its key positions were in many ways similar to his anti-materialist critique of modernity in the 1930s. He was conscious of the fact. Writing in the eighties, he said that 'to a certain degree we were antecedents of what in the 1960 s became radical, anti-capitalist environmental movements struggling for decentralization, pro-agricultural policies, and a simpler way of life. ${ }^{75}$ There is no question that anti-materialism was a core concept throughout Lindholm's life-seemingly the only one to bridge the gap between his first and second political phases.

The idealization of the worker and the idea of Nazi Germany as a workers' state, also lost their importance in his postwar conversion. The idolatry

73 RA, SE/RA/720834, Sven Olov Lindholm 'Soldatliv \& Politik, pt. 2, 108: 'En gång-1. maj 1974-anförtroddes jag att bära fanan åt Vasa FNL-grupp vid demonstrationen från Kungsträdgården till Hötorget. Det var 12000 i tåget. På Kungsgatan tänkte jag på, att här marscherade mina "egna trupper" för snart 40 år sedan under fanor med samma färgerblå-gul-röd—och jag tyckte det var något symboliskt i detta: innerst inne är det ju samma rättsbegrepp som driver mig nu som då, fast det tar sig andra uttryck.'

74 Sven Olov Lindholm, Döm ingen ohörd (Lund, 1968), 27-31; RA, SE/RA/720834, 'Soldatliv \& Politik, pt. 2, 130-137.

RA, SE/RA/720834, manuscript used in interview 1981, 74 . 
of the worker had been based on the distinction between productive Swedish workers and exploitative Jewish capitalists. This anti-Semitic foundation did not exist, and productivity was questioned, or even regarded as a kind of exploitation in itself. The idea of the Third Reich as a socialist role model was also abandoned. Interestingly, though, no other country appeared to replace it, then or in the sixties and seventies. For many of Lindholm's new friends on the New Left, the Cultural Revolution in Maoist China was the new socialist frontier. This was never Lindholm's position. As far as I can see, he mentions Mao Zedong as a source of inspiration just once, very briefly. ${ }^{76}$ The idea of a specific country as the embodiment of socialism was rejected. Rather, he spoke of a 'world government' as the only possible way of saving the planet from the atrocities of mass starvation and nuclear war. 'National socialism', he now understood, 'was the first step towards world socialism. The nation was reduced to the mean, but socialism was a goal in itself. ${ }^{77}$

\section{Conclusion}

In sum, it can be said that Lindholm's ideas in his party years largely corresponded to what for many people would count as 'typically' National Socialist: The racial conflict between Jews and Swedes was fundamental, and was supported by conservative catchwords and themes as a deep-rooted and emotional alignment to the soil and a critique of the non-authentic man of modern society. These themes were matched by strong support for the armed forces, while the markedly militarist aesthetic of the movement also contributed to such an assessment. However, there were other elements that contradicted or modified this view. Crucially, there was the idea that the struggle between Jews and Swedes was fundamentally a social conflict between capitalists and workers, and a number of strikingly Marxist ideas followed from this version of 'ethnic class struggle'. Ideas about the threat of exploitation that loomed over the value of work or the imperialist reach of capitalism were examples of this tendency. It should also be said that many of the conservative themes were in fact not truly conservative. The criticism of materialism and the culture of the machines, the ambition to buy the favor of the workers with material goods, reducing materialism to a kind of bribery, not to mention the idea of cultivating the soil instead of exploiting it, were all prominent themes for the New Left

76 RA, SE/RA/720834, manuscript used in interview 1981, 105.

77 RA, SE/RA/720834, 'Soldatliv \& Politik,' pt. 2, 132-33. 
in the 1960 s and 1970 os. $^{78}$ It would be reasonable to assume that these themes provided for a smooth transition to Lindholm's new ideological home.

In the event, this was partly the case. The most striking paradox was that most of Lindholm's Marxist traits, identified here as such, tended to fade away as he moved left along the ideological spectrum. In a vociferously antiMarxist ideology such as National Socialism, these traits were conspicuous. Their disappearance did little to remove the contradictions, rather the contrary. In Michael Freeden's terms, every core concept with the exception of anti-materialism that we see in Lindholm's writings then 'travelled' from core to periphery during his reevaluation. The fact that they all (to a different degree, one should add) made the same journey illustrates an important aspect of Freeden's thought: the concepts in the core cluster were interdependent, and formed a more or less coherent body of ideas. Anti-Semitism, anticapitalism, (parts of) anti-imperialism, the idealization of the worker and the view on Nazi Germany were, as shown, themes that were closely linked. In this sense, anti-materialism was on the side. It has been noted that there was a degree of tension between the ambition to take charge of the surplus values of production and the criticism of material production per se. The fact that the importance of every concept linked to the all-embracing perspective on ethnic material conflict decreased actually improved coherence in Lindholm's ideological message in his 'second phase'.

This article thus contributes to the field in two areas: it problematizes our understanding of National Socialism as a fundamentally anti-Marxist ideology, and it provides an idea of a possible ideological link between National Socialism and the New Left. Indeed, to some extent it also problematizes our understanding of the New Left as fundamentally Marxist, with its marked criticism of modernity. But why did Lindholm move along the political spectrum? How to explain his choice of the New Left? Was it a shift at all? As we have seen, he himself was sometimes hesitant about this last question-certainly, on several points he thought himself to have been a leftist politician all along. Yet taken as a whole, his conversion may be seen as a consequence of an ideological transformation from two sides; on Lindholm's part and on the part of the political left. In simplified terms, there were two dimensions to Lindholm's socialism: anti-materialism/idealism, and the nation as an arena for necessary social progress. 'Idealism' was a concept he often used himself, and it was of course integral to his anti-materialism. While there was great continuity when

78 For the critique of the one-dimensional man of modern materialist society, see, of course, Herbert Marcuse, One-Dimensional Man: Studies in the Ideology of Advanced Industrial Society (London: Beacon, 1964). 
it came to this theme, the idea of the nation as the superior political entity was gradually transformed. In the party years, he wrote that a true community of people can never be obtained without social justice for those of small means, and that social justice, in turn, can never be obtained if people are not transformed from within. This less egocentric man was still Lindholm's starting point thirty years on, but now the nation was no longer the limit: when a community of just nations was in place, restored from below by their newborn citizens, the long-term aim will be to form a world government, a global state, as he wrote in Döm ingen ohörd..$^{79}$ Nationalism had become internationalism, and was combined with a broad anti-materialism/idealism.

On the other hand, for the political left, broadly defined, it was internationalism that had ideological permanence. However, the focus on materialism and the possession of the means of production - traditional themes in the ideology of the labor movement-at least partly gave way to non-consumerism and criticism of modernity in the 196os and 1970s. At this end of the political spectrum, materialism had become anti-materialism and idealism.

Using this simplified idea of two axes, Lindholm and the New Left can be said to converge in an ideological position that was idealist and international socialist:

Imagine if the future of the world could be symbolized - not by the gigantic toxic mushroom cloud but by the eternally verdant tree of the world, or by a sunlit temple, whose freestanding pillars are the nations, the peoples, who in unity carry the state of the world, with the following words carved on the frieze: 'Do unto others as you would have them do to you.' 80

This is the final paragraph in Döm ingen ohörd from 1968. Apart from quoting the Gospel of Matthew, it captures the New Left's and Lindholm's ideological ambitions in the sixties quite well: their hopes for global, idealist socialism.

79 Sven Olov Lindholm, Döm ingen ohörd (Lund, 1968), 27-31.

8o Sven Olov Lindholm, Döm ingen ohörd (Lund, 1968), 31: 'Tänk om väldens framtid kunde symboliseras—ej av den gigantiska giftsvampen utan av det evigt grönskande världsträdet—eller av en solbelyst tempelbyggnad, vars fristående pelare bildas av de olika nationerna, folken, som i enighet bär upp det gemensamma världsriket, där på takfrisen står inristade orden: “Allt vad I viljen, att människorna ska göra Eder, det gören I och dem!"' 